\title{
人間・機械系の設計 $(3)$
}

\section{4. システムの評価と決定}

システムを評価するのにその評価基準がなくてはなら ない，たとえば経済的自動車というのは単位距離あたり ・ガソリン消費量を基準にして測る．そこで人間・機械 システムの基準について調べて行こう.

システムの性能をあらわす 1 つの尺度としてシステム の信頼性がある.これは単位時間当り, システムの故障 を起こす確率で定義する．故障の確率は機械故障も人間 のエラーもその中に含まれるので，人間のエラ一を起こ す確率を推定しておかないとシステムの信頼性をいうこ とは出来ない．次号でのべるシステムの有効度の話しは すべて基準値が故障確率の関数であらわされている．基 準值をある值に固定したとき，すなわち基準値を決めた ときシステムが評価される.

システムはある基準に对して評価されるものである が，この評価方法には体系的で，かつ定量的な方法と非 公式な方法とがある．体系的評価法は利害関係がいちじ るしいときには一番のぞましい方法である.

高温熱作業における人間の作業能力は, 熱が人体に対 する影響の基準として用いられる．人間・機械システム ではヒューマン・ファクタがシステム評価に大きく影響 するので，人間作業能力の関数として基準を作る場合が 多い.

\section{$4 \cdot 1$ システムの価値}

システムの価值を裏づけるものとしてシス テムの投資に対する利益，技術的新らしさ， 性能，信頼性等がある.これらはシステムの 価値を 1 つの基準に照らして評価しょうとす

* 慶応義塾大学工学部 Engineering Faculty, Kio Univ.

** 日本電気株式会社, 技術管理部, Nihon Elect: ic, Co.

林喜 男* 大川 雅 司**

るもので, システムの価值をあらわす断面ににすぎない. 古典的, 経済学的な考え方によると「あるものの価值 はそれを得るために他の誰かが支払う代償で決定され る」といわれている. すなわち買い手，売り手双方とも にその取り引きで利益を得ることの出来る価格が存在 し，この価格が高ければ高い程価值があることになる.

こういう観点からながめると, システムの価值は需要 と供給のバランスから決まってくる.

システムの価值は図 1 にみられるようにシステム性能 費用, 信頼性, 時間, 柔軟性等の関数であらわされる. たとえばシステムの価值がある基準性能以下である時に は価值が低いが，それ以上になると，a のように価值は

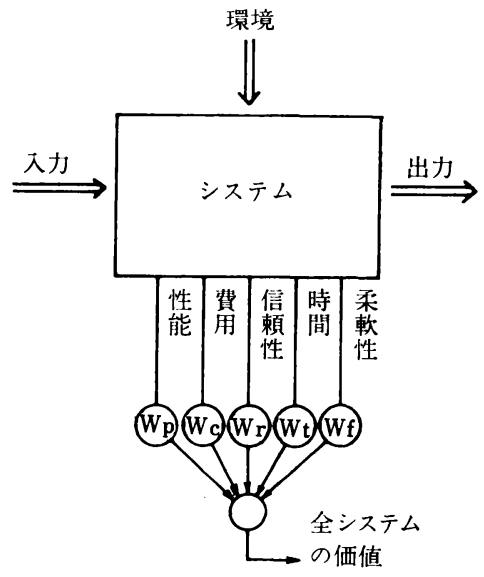

図 1 システムの価値

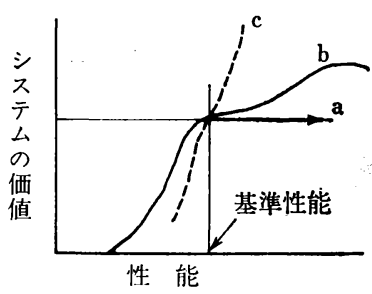

図 2 システムの価値と性能

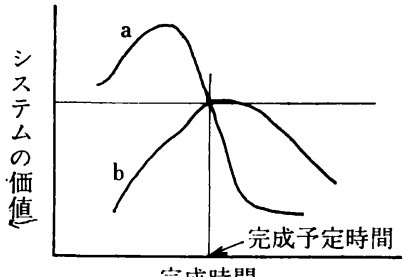

完成時間

図 3 システムの価值と完成時間 
上がらないか， c のように急速に上がるか，bのように 間であるかのいずれかになる（図 2)，ａの場合は性能 が基準よりよくてもそれを発揮する場所がないので，価 值を発揮出来ない，c の場合は性能がよければよい程価 值が出てくるといったタイプで, 戦闘機などはこの例で ある. 図 3 はシステムの価值と完成時間との関係を示し ている. a のタイプは完成時が予定よりもはやいと非常 に価值が上がるが，あまりはやいとその保管のための費 用のためその価值が下がってくる. b のタイプは完成時 間が予定よりはやいと，他の施設とのか稀合いでかえっ てシステムの価值が下がってしまう，もちろん予定時間 よりおくれてしまっては，ともにその価值は下がる．費 用や信頼についても図 4 , 図 5 にみられるように, シス テムの価值はシステムの費用や信賴性に大きく影響しな いものと, 影響がいちじるしいものに分けられる.

とくに人間がシステムの価值に大きく影響するもの は，その部分を機械化し，自動化することによってシス テムの価值を上げるか, 人間を訓練することによってシ ステムの価值を上げるかの 2 つの方法が考えられる.

たとえば装置工業で計算制御を行なう目的として，つ ぎの 5 つが考えられる.

（1）今までの装置より生産効率を上げ, 故障率も下げ たい。これはシステムの性能向上を目的としたものであ る.

（2）今までの装置に計測值の自動計測と異常事態を示 す警報とデータ（data）記録をさせたい。これはシステ ムに新しい機能を加えることを目的としたものである.

（3）今までの装置の手作業を機械化して省力化をはか りたい。これはシステムの費用を削減することを目的と したものである.

（4）今までの製品のばらつきをより小さくしたい.こ れは販売面の向上を目的としたものである.

（5）全工場を集中管理をして合理化をはかりたい.こ れは管理面の向上を目的としたものである.

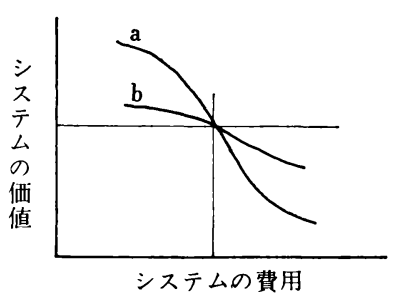

図 4 システムの価值と費用

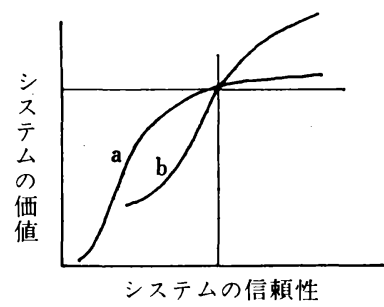

図 5 システムの価值と信頼性
これらの目的に対して計算機をプロセスに導入して. 手作業を機械におきかえ目的達成を行なおうとするもの である.人間が作業した場合と機械とで行なった場合と では，その特性がことなるので詳細に比較検討しなくて はならない.

チェスナットの“システム工学の方法”によるとシス テムの価値を決める要素として

(1) システムに対する制限条件

（2）システムの製作可能性とその利益性および製作不 可時の損失

（3）システムの諸目的の相対的重要度

(4) 環境の適応性

について考えておく必要があるといっている.

(2)はシステムが予定通り完成し作動したとしても, ど れだけの利益を得るのか，また予定通り満足に作動しな かったらどれだけの損失があるのか，またその確率はど の程度かを推定しておくことを意味している.

(3)はシステムの目的は多目的であるため, その相対的 重要度を決めておかないと, 多くの代替案の中から， 1 つのものを選ぶことが困難になるからである.

(4)は新しいシステムを完成するのには数年を要するか ら, 数年先の完成時の環境に適したものを作らなければ 意味のないものになるので, この点を考え, 充分先の見 通しのよい設計を行なわなくてはならないことを意味し ている.

\section{$4 \cdot 2$ システム評価基準とその要素}

システムの評価基準は

（1）システム性能

（2）システムの利益性，有効性

(3) システムの品質

等が考えられる. システムの性能をあらわす基準として 信賴性, 安全性, 持続性, 単純性, 両立性, 適応性とい ったものが含まれ, システムの利益性, 有効性の中には 費用有効度なる概念が含まれる。これらについ ては後にのべることにする. システムの品質も 性能と利益性と無関係ではないが, 出来上がっ たシステムの性能のばらつきを問題にするの が, システム品質の基準である.

そこでこれらの評価基準を人間・機械システ ムの評価に適用して考えて行こう。それにはま ず人間に対する基準を考える必要がある.

\section{人間のパフォーマンスの尺度}


厳密な意味で, 人間のパフォーマンスを人間の感覚, 知覚, 運動能等であらわされなければならないが，人間 ・機械システムの中の人間のパフォーマンスを測ること は非常にむつかかい，というのは人間のパフォーマンス は機械装置の性能特性とからみ合っているからである. たとえばタイピストのパフォーマンスはタイプライタの 性能に依存する.このようにシステムの中の人間のパフ オーマンスはシステムの機械特性によることが多い.

システムの性能を評価する時にヒューマン・ファクタ からシステム性能を評価する基準には, 生理学的指数,

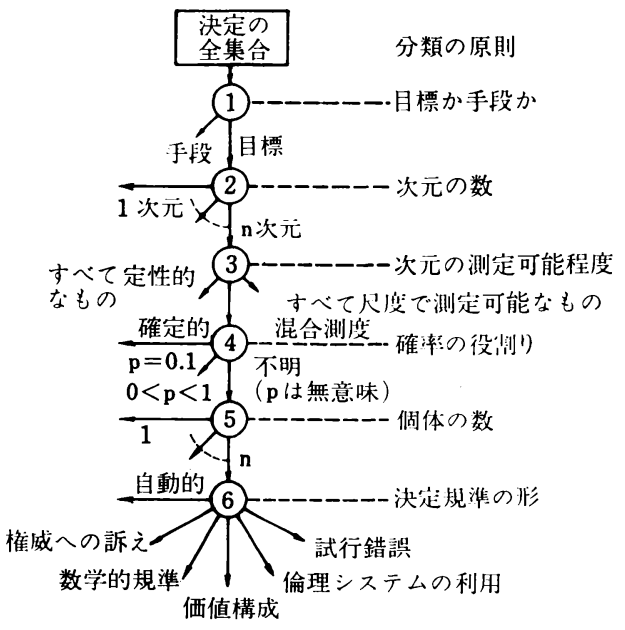

図 6 意志決定分野の分類

表 1 人間工学の立場から望ましい機械設計の進め方 (W. E. Woodson)

A. 準 備

$\mathrm{a}$ ，人間・機械システムの行なう仕事をはっきりすること

b . 設計の要求されている点, 制限されている点を確定すること

c.人間・機械システムが如何なる条件で操作されるものかその条件を明らか にすること

d. 人間・機械システムの各コンポネントの特性を決定すること

B. 選 択

a.与えられた仕事をなす各部の連繫の概略を示すこと

b. 提案された設計の各々について, その機械的特性, 設計の制限との比較, 期待される操作条件の下での信頼性などを考虑しながら, 各部の適切さにつ いて試験すること

c . 最も見込のある設計をえらび，それについて詳細な明細書を作ること

d. さらに必要ならば，えらばれた設計を進める結果として生ずる操作条件の コントロールの意義を明らかにすること

e . さらに経済性, 効率, 保守の難易などを明らかにすること

C. 検 討

人間・機械システムの全体をできるだけ実験的に評価すること，これが不可 能な場合には祭宫次ついてっ占含を行なって，全体の設計の評価に役立てる こと
主観点評価，事故数等をあげることが出来る. 生理学的 指数というのは人間の血圧, 拍動数, 脳波, 呼吸数とい った尺度で，これらの值がある基準值を超えた時は人間 ことって，好ましい状態ではないと判断し，そのような作 業を強いるシステムの性能はよくないと判断する．また いろいろのシステム性能の比較に人間の生理特性を基準 こして行なう場合がある.この場合はシステム性能が人 のパフォーマンスに大きく影響される場合に用いる.

主観的評価は人間のパフォーマンスを検査員の判断に つて評価する方法で，定量的な評価基準が得られない く用いられる.

事故数は人間の安全が重要な基準となっているシステ では，損傷数，死亡数等がシステム性能の基準とな

ヒューマン・ファクタが入ってくると人間の時間的変 動と人間間変動がシステム性能を決めるのにむずかしい 阔題を提供するから注意すべきである.

では一般に人間・機械システムの評価法にはどのよう な方法があるのか. W. E. Woodson は Human Engineering Guide for Equipment Designers (1964) の中 でヒューマン・ファクタを含んだ設計の正しい進め方 として表 1 のように準備, 選択，検討の手順をあげ，検 項目の中で人間・機械システムをできるだけ模型や 実験によってダイナミックな状態でテストし総合的な評 価を行なうように強調している.

\section{$4 \cdot 3$ システム評価值の} 決定 (トレード・オ

ᄀ) $=$ (trade-off)

シスラムの価值を決定する意 志決定の方法についてまず考え てみる.図 6 は意志決定のため の手順を示したものである。こ れには

1. 目標と手段の中から $1 つ$ を選定する.

2. 意志決定にあたって考慮 すべき価值の次元数あるいは異 なった尺度の数

3. 各価值尺度の可測程度

4. 確率の役割

5. 意志決定者の数

6. 使用する決定規準タイプ 
の 6 項目を考え, これにより意志決定の方法の分類を行 なうことが出きる.

（1）目標と手段の中から 1 つを選び出す.

システムの価值はその目標やそれを解決する手段を列 挙して，その中から重要なものを選ぶ.この場合すへて の目標や手段を列挙したかどうかはわからないが，予期 しない結果に鳘かないためにもあらゆる手段を講じて選 択候補を集める必要がある.

表 2 は典型的なシステム評価指標を示す。これらの項 目に関する記述は計画が進むにつれてより細部にわたっ て明確になってくる.

これらの目的を達成するためにシステムを設計すると お互いの目的間に強い正の相関関係があったり，負の相 関があったりして，全部の目的を達成できるシステムを 作りようがないことは当然である.そこでこのような場 合の意志決定をどうしたらよいのだろうか。

（2）意志決定にあたって考虑すべき価值の次元数ある いは異なった尺度の数とその可測性.

目的を評価する際に，それらの目的が同じ尺度の上で 論じられる場合は理想的な場合である.たとえばすへて の目的が費用という比例尺度の上で論じられるとすると その重要度はその上で評価される。

目的の測定の可能性と必要性に関する目的研究では, 目的を測定するときに使う単位で分類するとよいといわ れている. 表 2 はすべて同じ単位でシステム評価をしよ うとしているものであるが，実際目的の次元は多次元て あり，そういう意味で多次元目的関数を最大にする方法

表 2 典型的システム評価指標の一例

\begin{tabular}{lll|lll}
\hline 責 & \multicolumn{1}{c|}{ 務 } & accountability & 実 用 性 & practicality \\
適 応 性 & adaptability & 到 達 性 & reachability \\
アベィラビリティ & availability & 判 読 性 & readabiliy \\
キャパビリティ & capability & 年 長 性 & redundancy \\
一致 性 & compatibility & 信 頼 性 & reliability \\
複 雑 さ & complexity & 修 理 性 & repairability \\
制 御 性 & controlability & 転 換 性 & reversibility \\
弁 別 性 & discrimity & 安 & 全 & safety \\
自 在 性 & flexibility & 類 似 性 & similality \\
互 換 性 & interchangeability & 単 純 性 & simplicity \\
可 読 性 & legibility & 安 定 性 & stability \\
保 全 性 & maintainability & 適 合 性 & suitability \\
可 動 性 & mobility & 支 援 性 & supportability \\
オペラビリティ & operability & 訓 練 性 & trainability \\
可 搬 性 & portability & 運 搬 性 & transportability \\
\hline
\end{tabular}

はないのである.しかし大部分の場命，たとえば安全性 や利潤を最大にするという次元目的関数を決定する場合 には, ある程度安全性を金に換算して,より高度な価値 評価を行なう。

この目的にはそれぞれ測度の程度があり，測定尺度が 出来れば，それによって意志決定を行なうことが出来 る、目的の中には測定不可能なものがかなりあることも 注意すべきで，システムの適合性などは対象とする外部 条件の変化の先の見通しがきかないため, どの変化に適 合するのか，といった具体的な適合性が測定出来ないか らである。

目的の中には善意, 義務, 責任, 規律, 名声といった 概念を取り扱うものは比例尺度では測ることの出来ない 可測不可能な無形目的とよばれるもので，この評価がむ ずかしくなる.

(3) 確率の役割り

意志決定では決定論的なものと非決定論的なものとに 大別出来る.この考え方はゲームの理論の考え方である.

各選択候補のもたらす結果が常に不変であるなら確定 の条件の下で決定が行なわれる．たとえば雨が降ってい る時に莢を持って行くか，いかないかは決定論的にきま る. しかし雨が現在降っていないのに傘を持って行くか どうかは決定論的には行かず，確率的な要素を含んで来 る. 傘を持って行くという意志決定には雨が降るか，降 らないかという確率要素が重大な要因となる.この場合 不確定さがわかっていればリスクの条件下で決定が行な える.上の例では傘を持っていったが雨が降らなかった 時, 傘をわすれる時のリスクを傘 の雨が降った時の効用とのかね合 いで傘を持って行くか行かないか を決めることも出来る.

しかし選択候補と結果が分って いるが，その結果の出現確率が分 らない場合には決定は不確定性の 条件のもとで行なわれる.

（4）決定規準の型

人間の決定の多くは完全に意識 的にあるいは故意に行なわれるも のではない，生物的, 動物的本能 は自動的反射的に意志決定を行な っている.

つきによく行なわれる意志決定 の手法は工学でよく用いられる試 
行錯誤法である.この方法はあまり融通性のあるもので はない。これを成功させる鍵は学習の速さと記憶能力で ある. 電子計算機の出現により，この方法の利点を再評 価したが，機械主義の危険がある．たとえば砕くことも 出来ない, 定式化も出来ないような数学の問題を数学の 公理や定理をたくさん記憶した計算機にかければなんと かとくことが出来るかもしれないと思いこむのは間違っ ている.

簡単さからいうと試行錯誤法の次に権威への訴えによ る決定がある。この方法は目的が無形の場合によく用い られる.この方法は人の専断力，直観力，によってささ えられている。

数学的規準は決定規準のうちの最後のもので, システ ム設計にさいしてこの方法にたよれるものは実際上非常 に少くない.

\section{5. システムの有効性}

\section{$5 \cdot 1$ システム有効度概念}

\section{有効度評価の目的}

最近, システムの綜合評価尺度として用いられつつあ る「有効度（Effectiveness）」評価の目的はつぎのよう に集約できる。

1） システム設計の評価および選択的コンフィギュレ ーションの比較

2) トータル・システム計画に有用な数值的推測の準 備

3） システム寿命サイクルの各段階でシステムに期待 可能な運用要件の範囲に関するマネジメント上の準備

4）必要な修正アクションの指示

5）選択的修正アクションの効果比較

\section{有効度の定蓄}

有効度は総称的な表現であって，内容別にはシステム 有効度もしくはシステム性能有効度, コス卜有効度, 人 員性能有効度, システム安全有効度, その他などに分類 できる.

1） システム有効度 (System Effectiveness, SE)

この有効度は ARINC Research 社や RAND におけ る開発を基礎にしてアメリカ軍が組織的に導入したもの で軍によって定義づけた若干の相違がある，一般には，

「システムが規定条件下で動作させたとき，一定時間 以内は要求どおりの動作に成功する確率を指標とする綜
合システム尺度」もしくは,「システムが意図する職務を なし得る能力」などの表現がみられるが，空軍が組織し ている WSEIAC (Weapon System Effective Industry Advisory Committee) では,「システムが定められた使 命要求 (mission requirements) を達成するであろうと 期待される範囲をあらわす尺度」をいい，アベイラビリ ティ，ディペンダビリティ，ケイパビリティ（capability）の関数であるとし，この定義は MIL-STD-721B （信賴性，ヒューマン・ファクターズ，安全の有効度に 関する術語の定義 MIL-STD-447，721 A，778 を廃止 し集約したもの) でも利用している.

2）システム性能有効度 (System Performance Effectiveness, SPE)

この有効度は米海軍の NMSE (Naval Material Support Establishment) や NMS (Naval Material Command）が中心となってシステム有効度から流出さ れた概念で，「特定の環境条件において確立された時間 枠内で指定使命の完成が期待できる範囲の尺度」と定義 している.

3）人員システム有効度 (Personnel System Effectiveness, PSE)

「システム・プランナーが意図したシステム使命の達 成に対するシステムの人間コンポネントの機能上の相対 的能力レベル」と規定する.

4）システム安全有効度 (System Safety Effectiveness, SSE)

「システムにおける構成要素もしくは構成要素間の久 陥によって生ずる災害の潜在性が最大限に排除され，シ ステム全体が最適条件下にある確率」をいい，従来のコ ンポネント安全とは異なるシステム安全の立場からの綜 合評価尺度である。

5）コスト有効度 (Cost Effectiveness, CE)

「意志決定者がシステムに関して誘導されると支払わ れる資源との関連について定義づける尺度」をいい，シ ステムの選択的決定に必要な一種のマネシメント・ッー ル (management tool) となる.

\section{$5 \cdot 2$ 有効度の側面と評価プロセス}

有効度のうちで，とくにシステム有効度（システム性 能有効度も含む）には保証と評価からなる 2 つの側面が ある.

ここで保証的側面とは製品保障（ここではシステム保 障，信頼性保障，保全性保証などを含む広義の意）に必 
$\longmapsto$ 構想段階 $\longrightarrow$ 定義段階
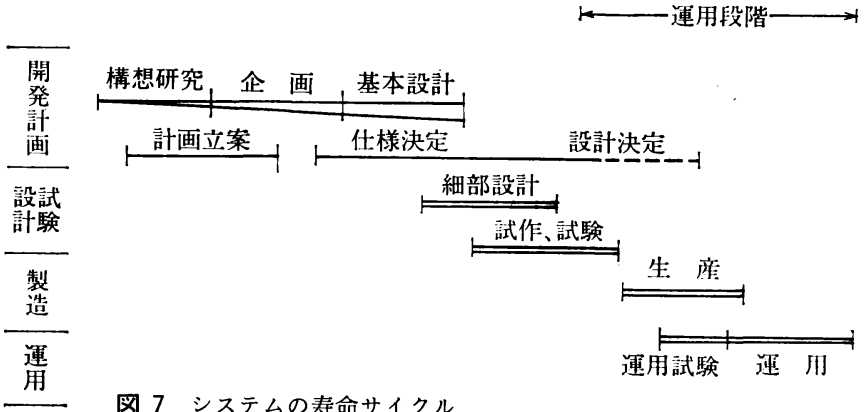

要なプログラム（設計，開発，製作，試験） に適用する管理技術を意味する。

プログラムシステムは図 7 のシステム寿命 サイクルのうち, 構想, 定義, 取得の各段階 で適用し，

機能/システム分析

信頼性（分析と試験）

保全性（分析と試験）

評価的側面とは有効度を定量的に評価する ための測定技術を意味し，マネジメント上の 役割としてつぎのようなものがある.

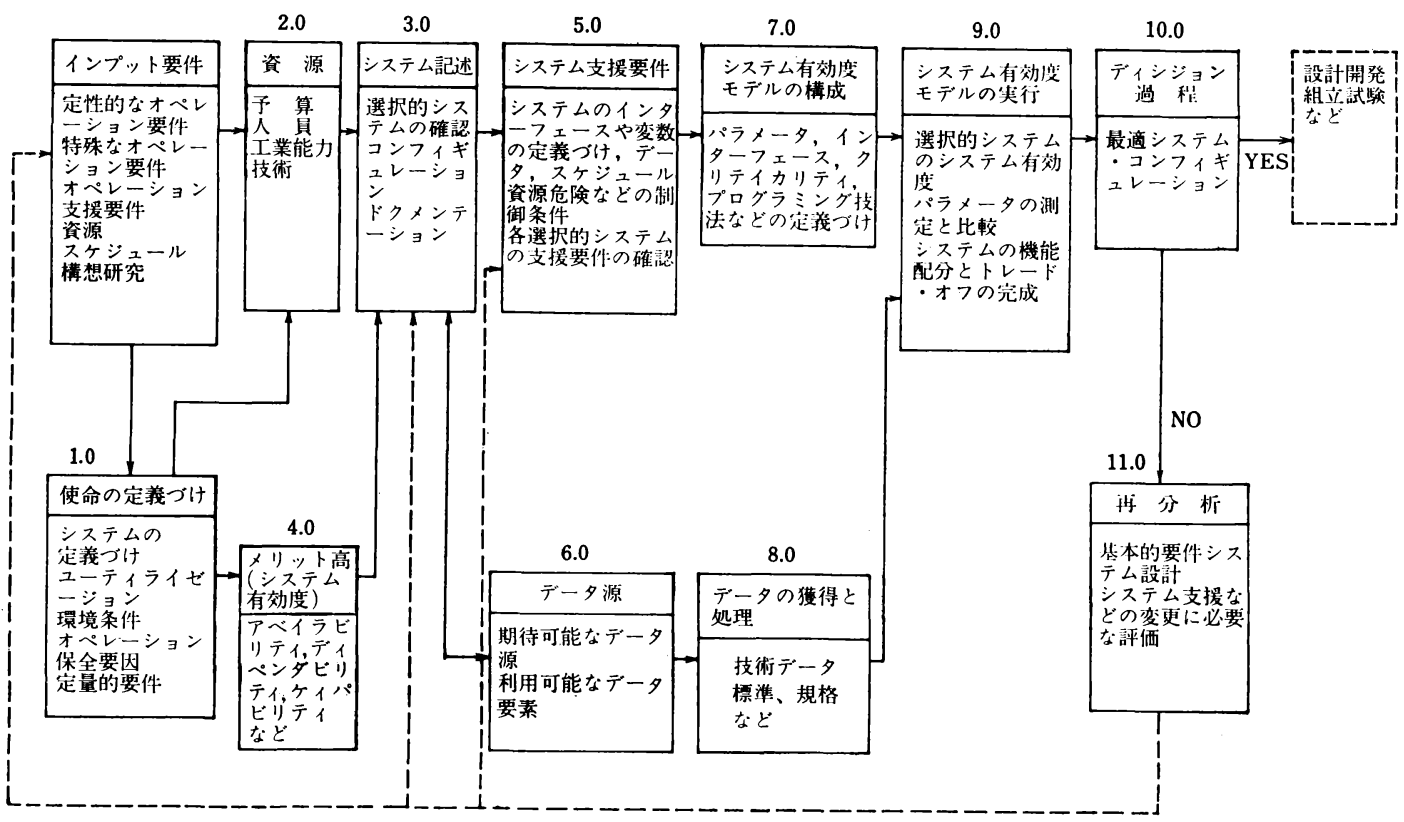

図 8 システム有効度の測定評価サイクル

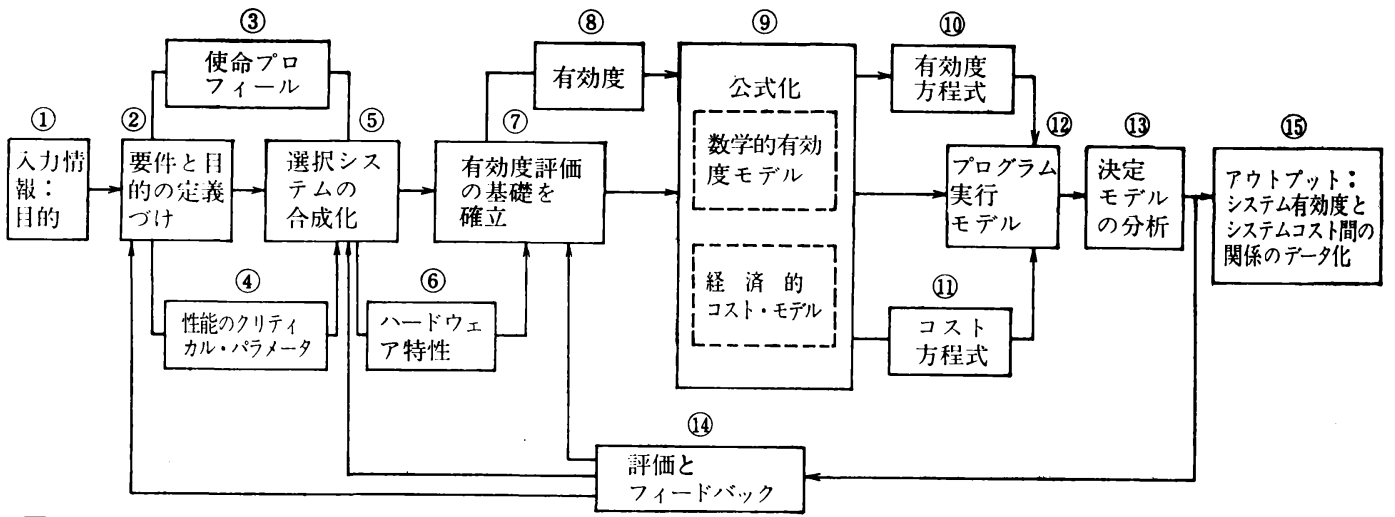

図 9 システム分析／コスト有効度プロセス 
表 3 システム有効度モデルの方程式

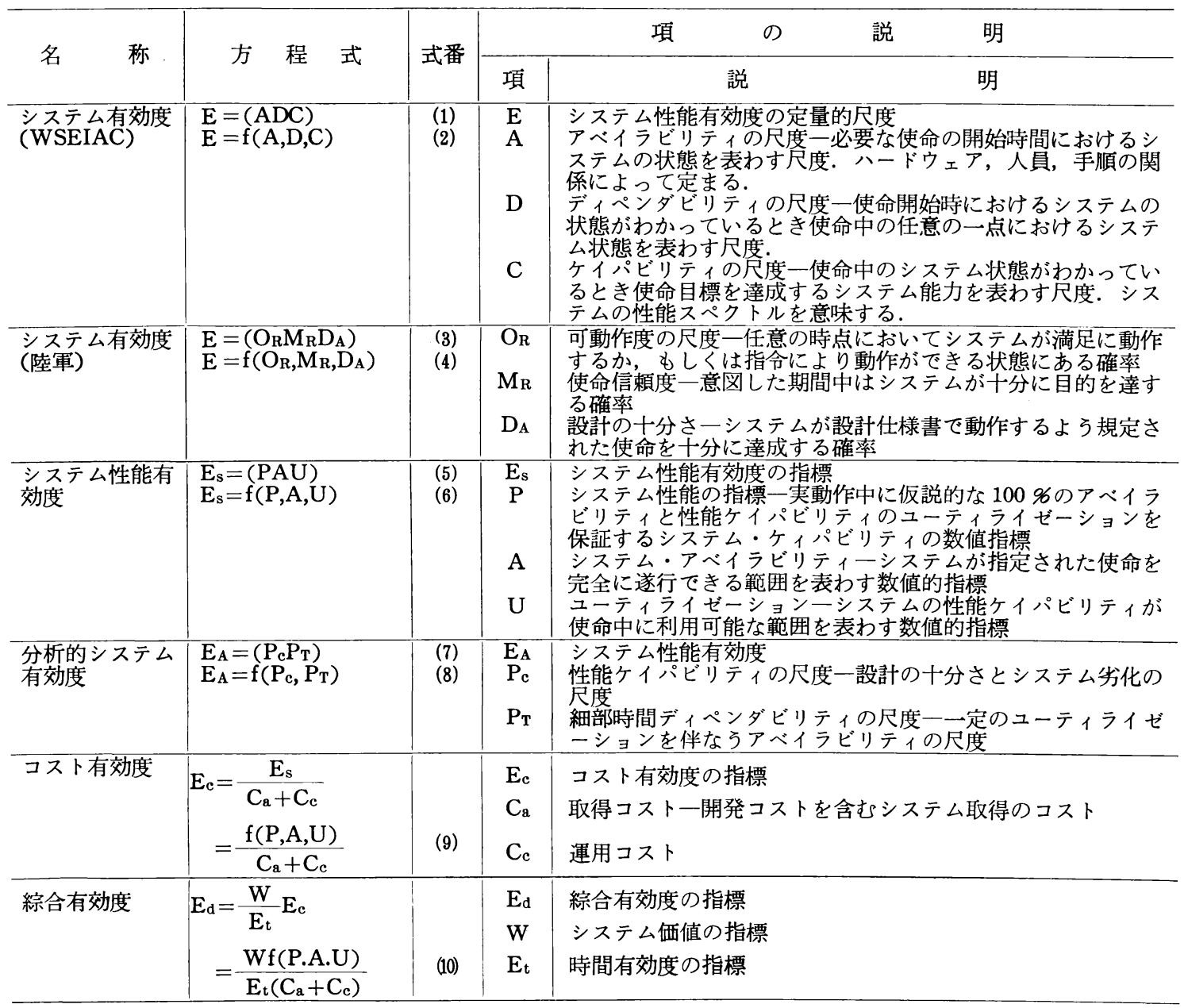

1）要件の定義づけ（有効度要件を明確化する方法, 有効度の定量的, 定性的要因の明確化など）

2) データ取得（プログラム上の意志決定過程に適合 する形式で取得）
3）技術開発（有効度測定に必要な分析技術，設計審 查, 綜合試験法などに関係ある測定／評価法とプログラ 么技術の開発）

4）要員の養成（有効度技術の実施に必要な要員の養 成)

5）プログラムの計画

評価的側面は一般に分析的予側法やモ デル法を用いるが，総括的なシステム有 効度測定・評価サイクルは WSEIAC が 図8のようにフィードバック・ループを 伴なう典型例を指定している。 また， ARINC Research 社が示すシステムー 分析／コスト有効度プロセスは図 9 のよ

図 10 システム有効度（陸軍型） 
うになる。

既述のように有効度の構成要因は，たと えばシステム有効度のように同一名称で呼 ばれるものでも一様ではない，有効度モデ ルの形で公表されている方程式の項を集約 して説明すれば表 3 のようになる.

さらにシステム有効度 (WSELAC と陸 軍), システム性能有効度, システム安全 有効度について細部を例示すれば図10 12 のようになる。

\section{参考文献}

1) G. J. Hahn \& S. S. Shapirs ; Statistical Model in Engineering, Wiley \& Son Ine., ' 67

2） A. D. ホール著; システム工学方法論 共立出版, '70

3）大川雅司；人間・機械システムの機能 配分, 人工誌, 5(6), 371 378, '69

4) ARIVC Research Corp ; Guide-book for Systems Analysis/Cost Effectiveness, ' 69

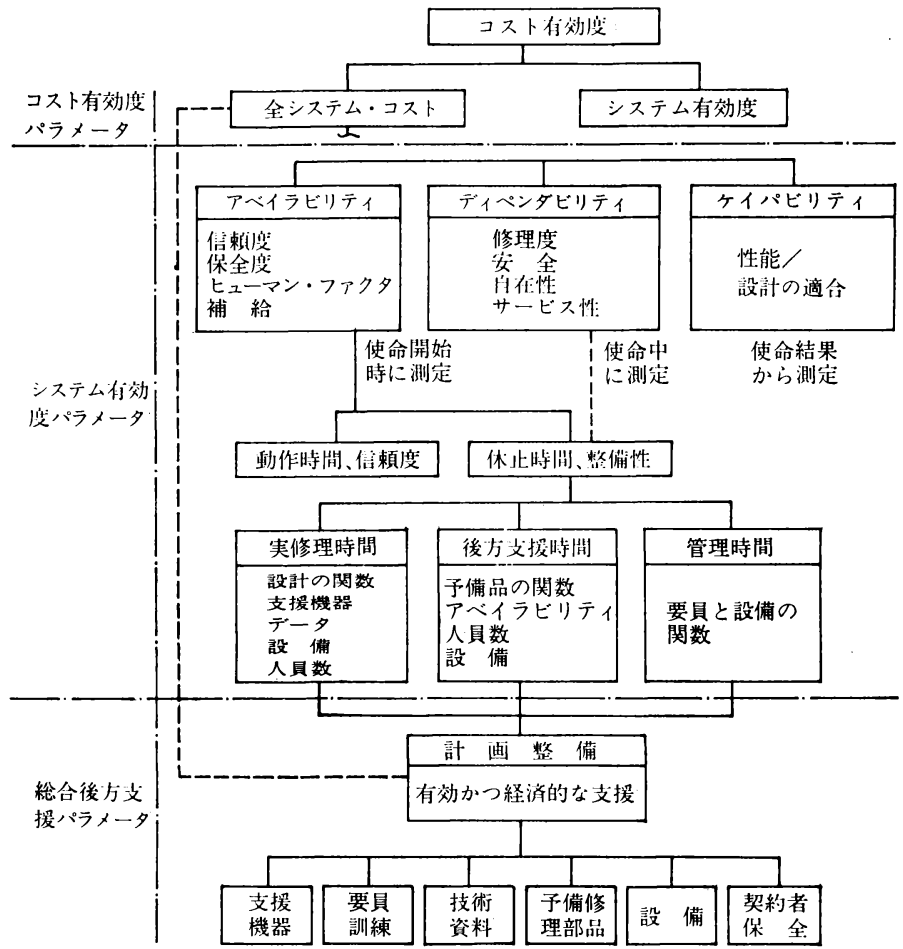

図 11 有効度の要因構成 (システム有効度一WSEIAC 型)

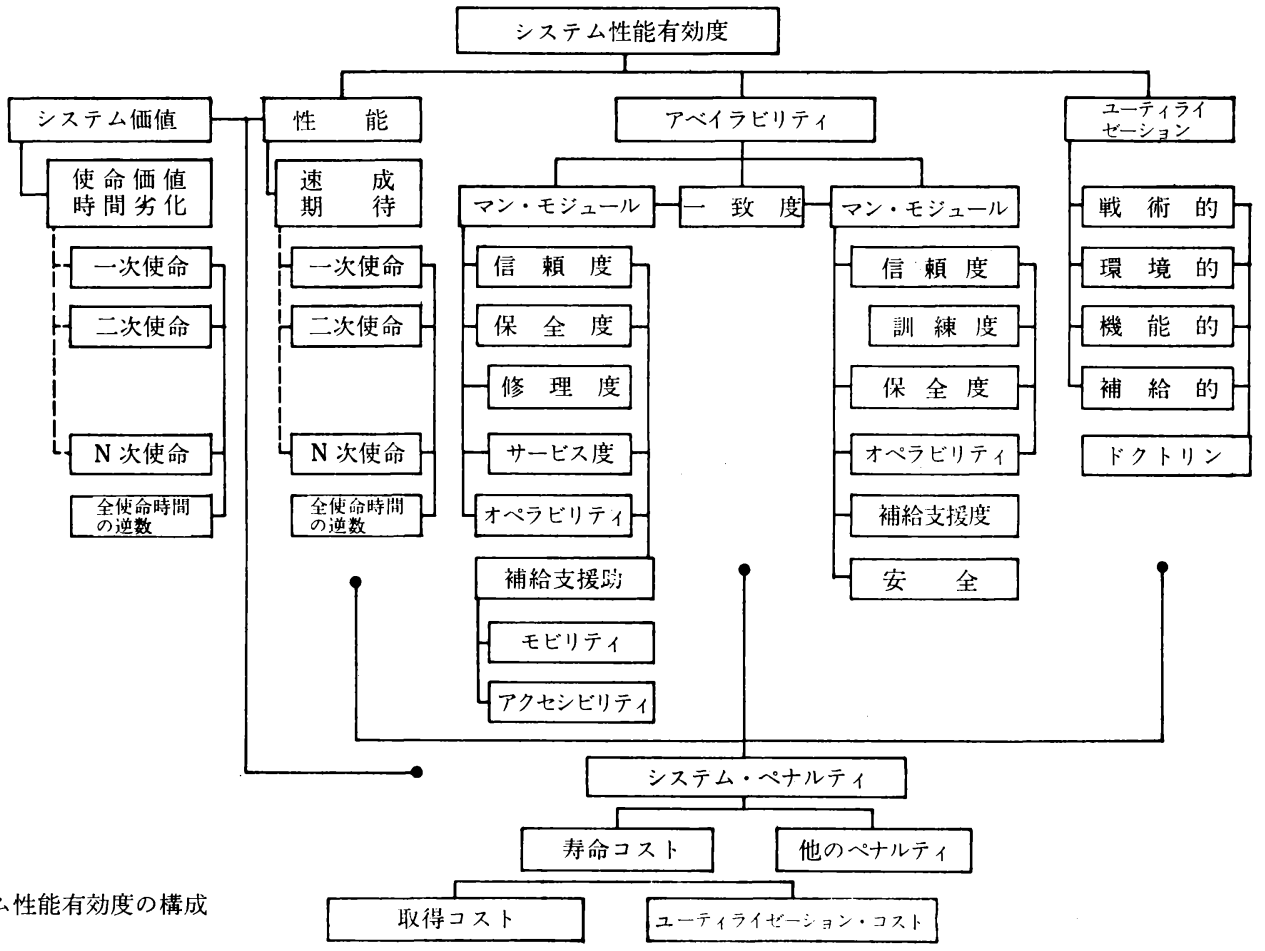

